\title{
Faktumtidspunktet ved konkurranserettslig inngrep mot foretakssammenslutninger ${ }^{1}$
}

\author{
Eirik Østerud
}

Eirik $\emptyset$ sterud er professor ved Institutt for privatrett, Det juridiske fakultet (UiO)

eirik.osterud@jus.uio.no

\section{Sammendrag}

Konkurranseloven $\S 16$ pålegger Konkurransetilsynet å gripe inn mot konkurranseskadelige foretakssammenslutninger, og slik inngrep krever en prediksjon av foretakssammenslutningens virkninger. Utfallet beror på de godtgjorte faktiske omstendighetene på tidspunktet for tilsynets vurdering. Emnet for denne artikkelen er det rettslig relevante faktumtidspunktet for Konkurransetilsynets inngrepsvurdering, Konkurranseklagenemndas klagesaksbehandling og domstolskontrollen med inngrep. Det argumenteres for at Konkurransetilsynet skal bygge på faktum på vedtakstidspunktet - ikke «tidspunktet for foretakssammenslutningen», slik tilsynet har fremholdt med den implikasjon at faktiske hendelser $f ø r$ vedtak har blitt avskåret relevans. For Konkurranseklagenemnda tilsier forvaltningslovens klageregler at nemnda skal ta i betraktning senere tilkomne faktiske omstendigheter. Konkurranselovens nyskaping fra 2017 om at "[r]etten kan prøve alle sider av saken», taler på samme måte for domstolskontroll med saken slik den står på domstidspunktet. Konkurranseklagenemndas og domstolens nåtidsvurderinger er ikke avpasset Konkurransetilsynets enekompetanse til å tillate foretakssammenslutninger på avbøtende vilkår. Regelverket tilskynder uformelle avhjelpende tiltak under klage- og domstolsbehandlingen, som fjerner inngrepsgrunnlaget slik at foretakssammenslutningen skal klareres. Likevel mangler nemnda og retten kompetanse til å tillate foretakssammenslutningen på tilsvarende formelle avbøtende vilkår.

Nøkkelord: Konkurranserett, foretakssammenslutninger, faktumtidspunkt

\footnotetext{
${ }^{1}$ Takk til Markus Jerk $\emptyset$, postdoktor ved Institutt for privatrett, Det juridiske fakultet (UiO), for innsiktsfulle kommentarer til et artikkelutkast og for interessante diskusjoner om problemstillinger diskutert i artikkelen. Takk også til Nicolas Amilien Simon, tidligere vitenskapelig assistent ved Institutt for privatrett, Det juridiske fakultet (UiO), for bistand med notehenvisninger, kilder og språkføring. Synspunktene som kommer til uttrykk er artikkelforfatterens.
} 


\section{$1 \quad$ Innledning}

Temaet her er faktumtidspunktet for vurderingen av inngrep mot foretakssammenslutninger ved anvendelsen av konkurranseloven ${ }^{2} \S 16 .{ }^{3}$ Med "faktumtidspunktet" menes skjæringstidspunktet der senere inntrådte faktiske omstendigheter ikke skal tillegges betydning. Det rettslig relevante faktumtidspunktet for Konkurransetilsynets inngrepsvurdering, Konkurranseklagenemndas klagesaksbehandling og domstolskontrollen med foretakssammenslutningsinngrep, følger dels av konkurranseloven, dels av alminnelig forvaltningsrett.

Konkurranseloven $\S 16$ pålegger Konkurransetilsynet å gripe inn mot kvalifisert konkurranseskadelige foretakssammenslutninger, enten med forbud eller med tillatelser på avbøtende vilkår. Foretakssammenslutningsbegrepet viser til omstruktureringer der tidligere separate foretak danner et enkelt foretak, enten ved fusjon, kontrollerverv eller opprettelse av operasjonelt selvstendige fellesforetak. ${ }^{4}$ Håndhevingen skjer forskuddsvis ved at meldepliktige foretakssammenslutninger som hovedregel ikke kan gjennomføres før myndighetsklarering foreligger. Myndighetsinngrep krever en prediksjon av meldte foretakssammenslutningers konkurransevirkninger. Konkurransetilsynets inngrepsvedtak kan påklages og bringes inn for Konkurranseklagenemnda, og søksmål om nemndas vedtak anlegges for Gulating lagmannsrett. ${ }^{5}$

Faktumtidspunktet kan avgjøre inngrepsutfallet, ettersom markeder og konkurranseforhold endres kontinuerlig. De godtgjorte faktiske forholdene på tidspunktet til grunn for inngrepsvurderingen avgjør om foretakssammenslutningen skal forbys eller tillates (eventuelt på vilkår).

I artikkelen drøftes faktumtidspunktet for henholdsvis Konkurransetilsynets inngrepsvedtak, Konkurranseklagenemndas klagevedtak og domstolskontrollen med nemndas vedtak. Til sammenlikning omhandles også faktumtidspunktet etter EU-/EØS-konkurranserettens fusjonskontrollregler, samt avgjørelsespraksis fra danske Konkurrencerådet.

Når det gjelder Konkurransetilsynets inngrepsvedtak, er spørsmålet om inngrepsvurderingen skal forankres i faktum på vedtakstidspunktet eller på et annet tidspunkt. I tilsynspraksis har det vært fremholdt at vurderingen skal bygge på det faktum som forelå på tidspunktet for foretakssammenslutningen. ${ }^{6}$ Problemet med uttalelsene er at foretakssammenslutningen normalt ennå ikke er gjennomført på vedtakstidspunktet. Tilsynet har i praksis likevel operert med et faktumtidspunkt $f ø r$ vedtaket treffes, slik at senere inntrufne forhold ikke har blitt ansett relevante. Denne praksisen medfører en $\varnothing$ kt risiko for materielt uriktige avgjørelser.

\footnotetext{
${ }^{2}$ Lov 5. mars $2004 \mathrm{nr} .12$ om konkurranse mellom foretak og kontroll med foretakssammenslutninger (konkurranseloven).

${ }^{3}$ Artikkelens problemstillinger gjelder tilsvarende for inngrep mot minoritetserverv, jf. konkurranseloven $\S 16$ a.

${ }^{4}$ Jf. konkurranseloven $\S 17$.

5 Jf. konkurranseloven $\S 39$ fjerde ledd.

${ }^{6}$ Konkurransetilsynets praksis behandles i punkt 4.
} 
For Konkurranseklagenemnda er spørsmålet om klagevedtak skal baseres på faktum da tilsynets vedtak ble fattet, på faktum på et eventuelt tidligere skjæringspunkt eller på tidspunktet for klagevedtaket.

Når det gjelder domstolskontroll, er spørsmålet om retten skal foreta en alminnelig legalitetskontroll med inngrepsvedtaket eller en ny prøving av saken slik den står på domstidspunktet.

Opplegget er som følger: Først gir jeg en kort presentasjon av konkurranseloven $§ 16$ og $\varnothing$ vrige regler om kontroll med foretakssammenslutninger. I punkt 3 og 4 diskuteres faktumtidspunktet for Konkurransetilsynets inngrepsvurdering og i tilsynets praksis. I punkt 5 og 6 drøftes faktumtidspunktet for Konkurranseklagenemndas klagevedtak og domstolskontrollen med inngrep. Noen avsluttende kommentarer følger i punkt 7.

\section{Konkurranselovens regler om kontroll med foretakssammenslutninger}

I tillegg til inngrepsbestemmelsen, består konkurranselovens foretakssammenslutningsregler blant annet av regler om meldeplikt ${ }^{7}$ og melding til Konkurransetilsynet, ${ }^{8}$ forbud mot gjennomf $\varnothing$ ring av meldepliktige transaksjoner $\mathrm{f} \varnothing \mathrm{r}$ og under Konkurransetilsynets saksbehandling, ${ }^{9}$ saksbehandlingsregler og -frister, ${ }^{10}$ og regler om klage til Konkurranseklagenemnda. ${ }^{11}$ Det gjelder ingen frist for å melde foretakssammenslutninger, men gjennomføringsforbudet må overholdes og foretakssammenslutningen må kunne beskrives i henhold til meldingskravene. ${ }^{12}$ Søksmål om Konkurransetilsynets inngrepsvedtak kan i utgangspunktet ikke reises, med mindre klageadgangen til Konkurranseklagenemnda er benyttet. ${ }^{13}$

Inngrepsbestemmelsen i konkurranseloven $\S 16$ første ledd første punktum lyder: «Konkurransetilsynet skal forby foretakssammenslutninger som i betydelig grad vil hindre effektiv konkurranse, særlig som et resultat av at en dominerende stilling skapes eller styrkes.» Bestemmelsen ble endret med virkning 1. juli 2016, og den fikk da tilsvarende formulering som den såkalte SIEC-standarden (Significant Impediment of Effective Competition) i EU-/EØS-rettens fusjonsforordning. ${ }^{14}$ Lovendringen ble særlig begrunnet i hensynet til harmonisering med EU-/E $\varnothing \mathrm{S}$-retten. ${ }^{15}$ Til sammenligning lød konkurranselovens tidligere særnorske inngrepsstandard slik: «føre til eller forsterke en vesentlig begrensning av konkurransen i strid

\footnotetext{
${ }^{7}$ Jf. konkurranseloven $\S 18$.

8 Jf. konkurranseloven $\S 18$ a.

9 Jf. konkurranseloven $\S 19$.

10 Jf. konkurranseloven $\S 20$.

11 Jf. konkurranseloven $\S 20$ a.

12 Jf. konkurranseloven 18 a. Se og Prop. 75 L (2012-2013) Endringer i konkurranseloven, side 105 og departementets vedtak 4. februar 2011 i sak 10/2546, klage på Konkurransetilsynets vedtak om ikke å behandle steg II i foretakssammenslutning mellom NIBE Industrier og ABK AS.

13 Jf. konkurranseloven $\S 39$ annet ledd.

${ }^{14}$ Reg. 139/2004 on the control of concentrations between undertakings (EUMR), artikkel 2.

15 Prop. 37 L (2015-2016) Endringer i konkurranseloven (Konkurranseklagenemnda, kartellforlik mm.), side 56 og Innst. 192 L (2015-2016) til Stortinget fra næringskomiteen om endringer i konkurranseloven (Konkurranseklagenemnda, kartellforlik mm)., side 10-11.
} 
med lovens formål.» Med internasjonal terminologi ble normen undertiden betegnet som en SLC-standard (Substantial Lessening of Competition). ${ }^{16}$

Avhjelpende tiltak er regulert i konkurranselovens $\S 16$ annet ledd. Bestemmelsen innebærer at dersom Konkurransetilsynet finner at avhjelpende tiltak foreslått av melderne vil avbøte konkurranseskaden foretakssammenslutningen kan føre til, skal tilsynet tillate foretakssammenslutningen på disse vilkår. Tilsynet kan videre knytte forpliktelser til vedtaket for å sikre at vilkårene oppfylles. Bestemmelsen avviker fra den alminnelige forvaltningsrettslige vilkårslæren ved at utredningsplikten for tilsynet er redusert. Tilsynet er dessuten avskåret fra å tillate en foretakssammenslutning på andre vilkår enn melder har foreslått. ${ }^{17}$ Ved klage over vedtak etter $\S 16$ annet ledd, kan Konkurranseklagenemndas vedtak bare gå ut på å oppheve eller stadfeste Konkurransetilsynets vedtak. ${ }^{18}$ Overtredelse av vedtak om tillatelse på vilkår, kan også gi grunnlag for overtredelsesgebyr. ${ }^{19}$

Etter Konkurranseloven skal det, som nevnt, foretas en forhåndskontroll med foretakssammenslutninger. Etter både SLC- og den gjeldende SIEC-standarden er inngrep betinget av at Konkurransetilsynet godtgjør at foretakssammenslutningen vil medføre kvalifisert konkurranseskade. Inngrepsvurderingen er en prediksjon av foretakssammenslutningens konkurransevirkninger. Bevistemaet gjelder følgelig ikke en fortidig begivenhet eller virkning, men virkningene av en fremtidig foretakssammenslutning.

Inngrep krever årsakssammenheng mellom foretakssammenslutningen og kvalifisert konkurranseskade. ${ }^{20}$ Årsakskravet krever en sammenligning av en predikert konkurranseutvikling med og uten foretakssammenslutningen (såkalt "future with vs future without»). ${ }^{21}$ Faktumtidspunktet for inngrepsvurderingen angir skjæringstidspunktet for hvilke senere inntrådte omstendigheter som ikke er relevante i prediksjonen.

En grunn til at faktumtidspunktet er praktisk viktig, er at transaksjoner knyttet til meldepliktige foretakssammenslutninger kan være tidkrevende. Det kan derfor gå lang tid fra eksempelvis en idé om foretakssammenslutning, via kommersielle sonderinger, forhandlinger, selskapsgjennomgang, intensjonsavtale, finansieringsavtaler, avtaleinngåelse, melding til Konkurransetilsynet,

\footnotetext{
${ }^{16}$ Se f.eks. Prop. 37 L (2015-2016) Endringer i konkurranseloven (Konkurranseklagenemnda, kartellforlik mm.), punkt 7.2.

17 Se nærmere Prop. 75 L (2012-2013) Endringer i konkurranseloven, side 144.

18 Jf. konkurranseloven $\S 20$ a første ledd femte punktum.

19 Jf. konkurranseloven $\S 29$.

${ }^{20}$ Se til eksempel forente saker C-68/94 og 30/95, Kali \& Salz, ECLI:EU:C:1998:148, avsnitt 110, Fornyings- og administrasjonsdepartementets vedtak 17. april 2009 i sak 8/3552, klage på Konkurransetilsynets vedtak V200822, Opplysningen Mobil - Aspiro Søk, punkt 7.1 og Konkurransetilsynets vedtak V2015-1, TeliaSonera - Tele2 / Network Norway, avsnitt 181-182, V2015-24, Coop - ICA, avsnitt 96-97, V2017-19, Eimskip - Nor Lines, avsnitt 240-241.

${ }^{21}$ For en analyse av konkurranserettslige årsakskrav, se Erling Hjelmeng, ‘Årsaksvurderinger i konkurranseretten særlig om det kontrafaktiske scenariet', Tidsskrift for forretningsjus, 2016 nr. 2, s. 10-45.
} 
tilsynsbehandling ${ }^{22}$, klarering eller inngrep, og eventuell klage til Konkurranseklagenemnda ${ }^{23}$ og videre domstolsbehandling, frem til eventuell gjennomføring (closing) av transaksjonen.

Over en slik tidsperiode kan markedssituasjonen endres. Foretakssammenslutningen og $\varnothing$ vrige strategiske valg kan utelukke andre alternativer. Forholdet til kunder, leverandører og konkurrenter utvikles. Kostnader kuttes, investeringer foretas, produkter, tjenester og produksjon fors $\varnothing$ kes forbedret, kontraktsporteføljer forvaltes og ansattes arbeidsforhold og forventninger justeres. Tilpasninger skjer på grunnlag av prognoser om fremtiden, risikovurderinger, tilfeldige hendelser, teknisk utvikling, endrede rammebetingelser og andre markedsaktørers preferanser, valg og agering.

Endrede markedsforhold innebærer, som nevnt, at tidspunktet som konkurransevirkningsanalysen knyttes til, kan bli avgjørende for om det foreligger inngrepsgrunnlag. Faktum på eksempelvis meldingstidspunktet kan tilsi inngrep, mens faktum ved utløpet av saksbehandlingsfristene kan tilsi ubetinget klarering, eller vice versa. På lignende måte kan det foreligge inngrepsgrunnlag for Konkurransetilsynet, mens faktum på Konkurranseklagenemndas vedtakstidspunkt eller på et senere domstidspunkt, kan tilsi at foretakssammenslutningen skal klareres.

\section{$3 \quad$ Faktumtidspunktet for Konkurransetilsynets inngrepsvurdering}

Faktumtidspunktet for Konkurransetilsynets inngrep er ikke uttrykkelig regulert i konkurranseloven. I lovforarbeidene nevnes ikke temaet og det foreligger ikke norske rettsavgjørelser om foretakssammenslutningsinngrep.

I Rt. 2013 s. 1187 forklarte Høyesterett at «[h]ovedregelen i norsk forvaltningsrett er at vedtak skal treffes på grunnlag av de opplysninger som foreligger på vedtakstidspunktet.» ${ }^{24}$ Tilsvarende gjelder omgjøringsvedtak. ${ }^{25}$ Det er imidlertid eksempler på at dette utgangspunktet er fraveket. Den nevnte høyesterettsdom, som gjaldt gyldigheten av Fiskeridirektoratets opprettholdelse av regionkontorets avslag på s $\varnothing$ knad om havbrukskonsesjon etter akvakulturloven ${ }^{26}$ og tildelingsforskriften, er illustrerende. ${ }^{27}$ Høyesterett fant at konsesjonsregimet innebar at myndighetene skulle se bort fra opplysninger innkommet etter søknadsfristen, slik at den forvaltningsrettslige hovedregelen måtte anses fraveket. Et annet eksempel er utlendingslova $\S 40$ fjerde ledd, hvoretter oppholdstillatelse for ektefeller kan nektes dersom det fremstår mest sannsynlig at hovedformålet med ekteskapsinngåelsen, vurdert på grunnlag av faktum på vigselstidspunktet (ikke vedtakstidspunktet) ${ }^{28}$, var å etablere oppholdsgrunnlag. Et annet eksempel finner vi i varemerkeloven ${ }^{29} \S 14$ tredje ledd første punktum, som angir at registreringsvilkårene «må være oppfy/t på søknadsdagen og registreringsdagen». Og i patentloven $\S 2$ første ledd er det

\footnotetext{
22 Jf. konkurranseloven $\S 20$.

23 Jf. konkurranseloven $\S 20$ a.

${ }^{24}$ Rt. 2013 s. 1187, avsnitt 34.

${ }^{25}$ Se Rt. 2013 s. 1424, dommer Skoghøys bemerkning: «Ved avgjørelsen av begjæring om omgjøring må forvaltningen ta stilling til det relevante faktum som foreligger på det tidspunkt det nye vedtak blir truffet.» ${ }^{26}$ Lov 17. juni 2005 nr. 79 om akvakultur (akvakulturloven).

${ }^{27}$ Forskrift 12. mars $2009 \mathrm{nr}$. 298 om tildeling av løyve til havbruk med matfisk av laks, aure og regnbogeaure i sjøvatn i 2009.

${ }^{28}$ Rt. 2013 s. 937, avsnitt 31 og 32.

${ }^{29}$ Lov 26. mars $2010 \mathrm{nr} .8$ om beskyttelse av varemerker (varemerkeloven).
} 
bestemt at patent bare meddeles oppfinnelser "som er nye i forhold til kva som var kjent før patentsøknadens inngivelsesdag, og som dessuten skiller seg vesentlig frå dette». ${ }^{30}$

Konkurranseloven $\S 16$ første ledd og konkurranselovens $\varnothing$ vrige bestemmelser gir derimot ikke holdepunkter for at faktumtidspunktet avviker fra det forvaltningsrettslige utgangspunktet om at vedtak skal treffes på grunnlag av faktum på vedtakstidspunktet.

Hensynet til å oppnå materielt riktige inngrepsavgjørelser taler også for vedtakstidspunktet, et hensyn som ble tillagt betydelig vekt ved utformingen av bevisreglene i tvisteloven. ${ }^{31}$ Til sammenligning vil, som nevnt, et faktumtidspunkt tidligere enn inngrepsavgjørelsen, utelukke senere inntrådte omstendigheter fra prediksjonen av foretakssammenslutningens konkurransevirkninger, selv om disse omstendighetene kan være avgjørende. Dette vil kunne føre til flere klarerte konkurranseskadelige foretakssammenslutninger og flere inngrep mot konkurransefremmende foretakssammenslutninger.

Konkurranseloven $\S 16$ første ledd er harmonisert med EU-/EØS-fusjonsretten. ${ }^{32}$ Harmoniseringsformålet kan tilsi at faktumtidspunktet for EU-kommisjonens inngrep er relevant for tolkingen og anvendelsen av konkurranselovens inngrepsstandard. ${ }^{33}$ Faktumtidspunktet for EU-kommisjonen har $\mathrm{i}$ det minste komparativ interesse. Tidspunktet er imidlertid ikke uttrykkelig regulert i fusjonsforordningen. ${ }^{34}$ Forordningens artikkel 10 (5) gjelder der EU-domstolen har annullert et foretakssammenslutningsvedtak, og bestemmelsen angir at ved fornyet behandling skal foretakssammenslutningen «be re-examined in the light of current market conditions.» Dette tilsier at også den opprinnelige inngrepsvurderingen skal bygge på faktum på avgjørelsestidspunktet. For $\varnothing$ vrig indikerer også gjennomføringsforordningen at faktumtidspunktet svarer til inngrepstidspunktet. ${ }^{35}$

EU-domstolens og Rettens avgjørelser kan også belyse faktumtidspunktet for EU-kommisjonens inngrepsvurdering. I Verband der freien Rohrwerke uttalte Retten at «the appraisal by the Commission of the compatibility of a concentration with the common market must be carried out solely on the basis of matters of fact and law existing at the time of notification of that transaction, and not on the basis of hypothetical factors, the economic implications of which cannot be assessed at the time when the decision

\footnotetext{
${ }^{30}$ Eksempel fra Jørgen Vangsnes foredrag «Nye bevis og nye omstendigheter - faktum som endrer seg», Juristenes Utdanningssenters kurs «Fakta i forvaltningsretten», Oslo 20. november 2017.

${ }^{31}$ NOU 2001:32 A Rett på sak, side 454: «Rettsregler om bevis kan altså føre til at det blir lagt et annet faktum til grunn for avgjørelsen enn det som er korrekt. Ved utformingen av rettsreglene om bevis, må man ha for $\varnothing y e$ at bevisreglene generelt må fremme materielt riktige avgjørelser. Det skal tungtveiende grunner til for å gi regler om bevis som skaper en risiko for at avgjørelsen i saken kan bli bygget på et uriktig faktisk grunnlag.»

32 Prop. 37 L (2015-2016) Endringer i konkurranseloven (Konkurranseklagenemnda, kartellforlik mm.), s. 56.

33 Ulike faktumtidspunkter for EU-kommisjonens og Konkurransetilsynets inngrepsvurdering svekker hensynet til lik rettsanvendelse, noe som kan gjøre inngrepsutfallet mer beroende på hvilken konkurransemyndighet som behandler foretakssammenslutningen. Foretakssammenslutninger kan overføres til behandling fra EUkommisjonen til Konkurransetilsynet og vice versa.

${ }^{34}$ Reg. 139/2004 on the control of concentrations between undertakings (EUMR).

${ }^{35}$ Reg. 802/2004 implementing Reg. 139/2004 on the control of concentrations between undertakings, artikkel 5
} (3). 
is adopted $\gg .{ }^{36}$ Poenget var at inngrepsvurderingen ikke skal baseres på hypotetiske forhold, og Retten tok ikke stilling til relevansen av faktiske hendelser mellom meldings- og vedtakstidspunktet.

I Tetra Laval la EU-domstolen til grunn at inngrepsvurderingen innebærer "a prediction of events which are more or less likely to occur in future if a decision prohibiting the planned concentration or laying down the conditions for it is not adopted. $\nu^{37}$ Uttalelsen tilsier at faktumtidspunktet svarer til vedtakstidspunktet. l easyJet Airline fremhevet Retten at "it is settled case-law that the legality of the contested measure must be assessed on the basis of the elements of fact and of law existing at the time when the measure was adopted $\gg{ }^{38}$ Når domstolskontrollen knyttes til faktum på vedtakstidspunktet tilsier det at det samme faktumtidspunkt gjelder for EU-kommisjonens inngrepsvurdering. At inngrepsvurderingen skal baseres på de faktiske omstendighetene på vedtakstidspunktet uttrykkes også i Impala, der Retten fremhevet at inngrep må være «supported by a concrete analysis of the situation existing at the time of adoption of the decision. ${ }^{39}$

Det er for $\emptyset$ vrig vanskelig å identifisere vektige hensyn som taler for et annet faktumtidspunkt enn vedtakstidspunktet. Konkurransetilsynet bør ikke, i konflikt med konkurranselovens formål ${ }^{40}$, forby konkurransefremmende foretakssammenslutninger eller tillate konkurranseskadelige foretakssammenslutninger, selv om de faktiske omstendighetene er endret i løpet av tilsynsbehandlingen.

Det kan nok være visse praktiske utfordringer forbundet med vurderingen av tidsnære faktiske hendelser, og konkurranselovens fristregler ${ }^{41}$ kan innebære at sent inntrådte hendelser ikke kan behandles like grundig som $\emptyset n s k e l i g$. Disse forholdene kan imidlertid ikke begrunne et utgangspunkt om et antedatert faktumtidspunkt med medfølgende $\varnothing k t$ risiko for uriktige avgjørelser. ${ }^{42}$ Forvaltningens utredningsplikt er

\footnotetext{
${ }^{36}$ Sak T-374/00, Verband der freien Rohrwerke m.fl. mot Kommisjonen, ECLI:EU:T:2003:188, avsnitt 170. Med henvisning til sak T-2/93, Air France mot Kommisjonen, ECLI:EU:T:1994:55, avsnitt 70. Se liknende sak T-342/99, Airtours mot Kommisjonen, ECLI:EU:T:2002:146, avsnitt 82. Se for øvrig Erling Hjelmeng, 'Årsaksvurderinger i konkurranseretten - særlig om det kontrafaktiske scenariet', Tidsskrift for forretningsjus, 2016 nr. 2, s. 10-45, på side 29.

37 Sak C-12/03, Kommisjonen mot Tetra Laval, ECLI:EU:C:2005:87, avsnitt 42.

${ }^{38}$ Sak T-177/04, easyJet Airline mot Kommisjonen, ECLI:EU:T:2006:187, avsnitt 203. Med henvisninger til forente saker 15/76 og 16/76, Frankrike mot Kommisjonen, ECLI:EU:C:1979:29, avsnitt 7; sak C-449/98, IECC mot Kommisjonen, ECLI:EU:C:2001:275, avsnitt 87; forente saker T-177/94 og T-377/94, Altmann m.fl. mot Kommisjonen, ECLI:EU:T:1996:193, avsnitt 119.

39 Sak T-464/04, Impala mot Kommisjonen, ECLI:EU:T:2006:216, avsnitt 250. For øvrig har Retten også uttalt at «the Commission cannot disregard binding agreements between the notifying parties, provided that their stipulations are lawful under the applicable national law.», jf. sak T-351/03, Schneider Electric mot Kommisjonen, ECLI:EU:T:2007:212, avsnitt 221.

40 Jf. konkurranseloven $\S 1$.

41 Jf. konkurranseloven $\S 20$.

42 Nevnes kan NUT 1958:3 Innstilling fra Komiteen til å utrede spørsmålet om mer betryggende former for den offentlige forvaltning (Forvaltningskomiteens innstilling), som fremhevet at «[p]rinsippet om at den materielle sannhet må danne grunnlaget for forvaltningsavgjørelsene» (side 160).
} 
dessuten begrenset til det som er «mulig før vedtak treffes». ${ }^{43}$ En mer fleksibel fristregulering er uansett å foretrekke fremfor en absolutt regel om et tidligere faktumtidspunkt. ${ }^{44}$

Et annet faktumtidspunkt enn vedtakstidspunktet vil også medføre notoritetsutfordringer. Det er ingen konkurranserettslig notoritetsordning knyttet til en idé om foretakssammenslutning, sonderinger, forhandlinger, selskapsgjennomgang, intensjonsavtale, inngåelse av bindende avtale etc. Foretakssammenslutninger følger heller ikke noen enhetlig transaksjonskronologi, og de kan til og med komme i stand uten direkte sammenheng med en transaksjon. ${ }^{45} \mathrm{~F} \varnothing \mathrm{r}$ et eventuelt inngrep, henleggelse eller fristutløp, er det kun meldingstidspunktet som har tilfredsstillende notoritet. Det gjelder likevel ingen frist for inngivelse av melding, slik at meldingstidspunktet styres av partene. Og selv om meldingstidspunktet har notoritet, er ikke det et argument for at det burde utgjøre faktumtidspunktet for inngrepsvurderingen. En slik rettstilstand ville heller ikke hindre at melder eventuelt inngir ny melding om samme foretakssammenslutning og derved flytter faktumtidspunktet, slik at senere inntrådte faktiske hendelser likevel må hensyntas.

Man kan, som antydet, seg for seg en rettstilstand med ulike faktumtidspunkter for ulike faktiske hendelser. Et mulig slikt skille kan gå mellom faktiske endringer relatert og urelatert til foretakssammenslutningen. For tilfeldige hendelser, regulatoriske endringer, andre markedsakt $\varnothing$ rers urelaterte markedsopptreden mv., kan en eksempelvis forestille seg at faktumtidspunktet svarer til vedtakstidspunktet, mens et tidligere faktumtidspunkt gjelder for hendelser påvirket av foretakssammenslutningen. I tillegg til at det vil være vanskelig å trekke seg slik grense, vil ikke et slikt skille fremme hensynet til flest mulig korrekte inngrepsavgjørelser. At involverte foretak, ansatte, ledelse, aksjonærer, investorer, kreditorer, konkurrenter, kunder, leverandører, rådgivere, kontraktspartnere mv. tilpasser seg en meldepliktig foretakssammenslutning, er ikke et argument for at tilpasningene ikke skal inngå i inngrepsvurderingen i den grad de har prediksjonsverdi. Ved ikke å tilkjenne slike faktiske hendelser relevans vil derimot prediksjonsgrunnlaget og treffsikkerheten ved rettsanvendelsen svekkes. Når Konkurransetilsynet skal gripe inn mot foretakssammenslutninger som vil forårsake kvalifisert konkurranseskade, er det heller ikke lett å se grunner til at faktiske hendelser som nettopp skyldes foretakssammenslutningen, likevel ikke skal inngå i vurderingen.

En forutsatt fare eller risiko for at markedsaktørene kan påvirke markedsforholdene før Konkurransetilsynets inngrepsavgjørelse - for å øke eller redusere inngrepsrisikoen - fremstår heller ikke som et vektig argument for et fremskyndet faktumtidspunkt. En slik risiko vil uansett ikke kunne forsvare et generelt antedatert faktumtidspunkt. Et tematisk avgrenset antedatert faktumtidspunkt ville uansett

\footnotetext{
${ }^{43} \mathrm{Jf}$. forvaltningsloven $\S 17$.

${ }^{44}$ Sml. Reg. 802/2004 implementing Reg. 139/2004 on the control of concentrations between undertakings, artikkel 5 (3) og 9 (1) (d).

${ }^{45}$ Foretakssammenslutninger komme i stand uten direkte sammenheng med en transaksjon, f.eks. der et foretak får de facto kontroll over et annet foretak fordi andre aksjonærer over tid unnlater å utøve sine aksjonærrettigheter eller der et foretak får de facto kontroll over et annet foretak fordi en annen aksjonær avhender andeler til tredjeparter. Eksempler på såkalte passive kontrollerverv finner man i sak COMP/M.3330, RTL/M6 og sak COMP/M.6957, IF P\&C/TOPDANMARK. I Kommisjonens Jurisdiksjonsmeddelelse (2008/C 95/01), avsnitt 21, forklares: "There may be an acquisition of control even if it is not the declared intention of the parties or if the acquirer is only passive and the acquisition of control is triggered by action of third parties.»
} 
ha måttet regulere hvilke markedsaktørers nærmere definerte markedspåvirkning som i fall avskjæres etter hvilket tidspunkt.

Det kan også spørres om hvordan markedsaktører eventuelt kan påvirke markedsforholdene for å øke eller redusere inngrepsrisikoen, og hvorfor dette i fall er et problem. En mulighet kan være at konkurrenter, kunder, leverandører eller andre tredjeparter, iverksetter eller varsler konkurransefremmende atferdsmessige markedstiltak påvirket av foretakssammenslutningen, som innebærer eller tilsier at det ikke foreligger inngrepsgrunnlag. At konkurransen av slike grunner styrkes, med den følge at foretakssammenslutningen ikke vil føre til kvalifisert konkurranseskade, kan vanskelig være et argument for at slike markedstiltak ikke er relevante eller skal avskjæres av et tidligere faktumtidspunkt.

At tredjepartsforetak iverksetter eller varsler konkurranseskadelige atferdsmessige markedstiltak påvirket av foretakssammenslutningen, som tilsier at det foreligger inngrepsgrunnlag, er heller ikke et argument for at slike tiltak skal avskjæres av et tidligere faktumtidspunkt med den følge at Konkurransetilsynet likevel ikke skal gripe inn. Iverksatte konkurranseskadelige markedstiltak kan være i strid med konkurranselovens forbud mot konkurransebegrensende samarbeid ${ }^{46}$ eller mot misbruk av markedsdominans. ${ }^{47}$ Hvorvidt varslede tiltak kan opprettholdes etter forbudsbestemmelsene, kan prejudisielt inngå i inngrepsvurderingen. Konkurransevirkningene av suksessivt meldte foretakssammenslutninger kan for $\varnothing$ vrig vurderes på grunnlag av kronologibetraktninger. ${ }^{48}$

Et annet tilfelle kan være at foretakene som inngår i foretakssammenslutningen, iverksetter eller varsler markedstiltak påvirket av foretakssammenslutningen, som innebærer eller tilsier at det likevel ikke foreligger inngrepsgrunnlag. Heller ikke her er det lett å se hvorfor tiltakene skal avskjæres av et tidligere faktumtidspunkt, med den følge at Konkurransetilsynet skal gripe inn. Dersom markedstiltakene innebærer at foretakssammenslutningen ikke oppfyller inngrepsstandarden, er det ikke grunnlag for inngrep. At tiltakenes konkurransebetydning og prediksjonsverdi må undersøkes konkret, er uansett på det rene. Slike markedshandlinger vil ikke være i konflikt med forbudet mot gjennomføring av meldepliktige foretakssammenslutninger før og under Konkurransetilsynets saksbehandling. ${ }^{49}$ Men forbudene mot konkurransebegrensende samarbeid ${ }^{50}$ og misbruk av markedsdominans, vil også her være til hinder for konkurransehindrende atferd. Dersom klarering skyldes at melder har gitt uriktige opplysninger om konkurransefremmende markedstiltak, kan det etter omstendighetene også gi grunnlag for overtredelsesgebyr ${ }^{51}$ straff $^{52}$ og senere inngrep etter alminnelige forvaltningsrettslige regler. ${ }^{53}$

\footnotetext{
${ }^{46}$ Konkurranseloven $\S 10$ og EØS artikkel 53.

${ }^{47}$ konkurranseloven $\S 11$ og EØS artikkel 54.

${ }^{48}$ For en redegjørelse av praksis under EUs fusjonsforordning, se Alistair Lindsay \& Alison Berridge, The EU Merger Regulation: Substantive Issues, $5^{\text {th }}$ edition, Sweet \& Maxwell 2017, s. $243 \mathrm{flg}$.

49 Jf. konkurranseloven $\S 19$ og sak C-633/16, Ernst \& Young mot Konkurrencerådet, ECLI:EU:C:2018:23.

${ }^{50}$ Konkurranseloven $\S 10$ og EØS artikkel 53.

51 Jf. konkurranseloven $\S 29$.

52 Jf. konkurranseloven $\S 32$.

53 Jf. forvaltningsloven $§ 35$.
} 
Et siste tilfelle kan være at foretakene påbegynner eller varsler konkurranseskadelige markedstiltak for det tilfellet at foretakssammenslutningen ikke blir klarert. Tenkte tilfeller er avtaler eller ensidige tiltak som skal iverksettes dersom foretakssammenslutningen ikke implementeres, som kan svekke konkurransen uten foretakssammenslutningen, slik at det ikke foreligger inngrepsgrunnlag. Som illustrasjon kan nevnes Høyesteretts avgjørelse i Rt. 2012 s. 18, der Kistefos ikke fikk medhold i at fylkeslandbruksstyrets vedtak om å nekte Kistefos konsesjon til erverv av to skogteiger etter konsesjonsloven, skulle kjennes ugyldig. ${ }^{54}$ Fylkeslandbruksstyret hadde lagt til grunn at ervervet ikke ville skape en god arrondering av Kistefos' eiendom, men at betydelige fordeler i stedet kunne oppnås ved at naboer kunne erverve teigene som tilleggsjord. Kistefos anførte blant annet at vedtaket var basert på feil faktum og viste til at fylkeslandbruksstyret ikke hadde hensyntatt Kistefos uttalelse om at salg til naboene ikke kom på tale. Høyesterett kommenterte at "[k]onsekvensen av [Kistefos" syn] ville imidlertid være at en konsesjonssøker så å si på egenhånd kunne hindre en vurdering av andre alternativer ved - som her - å påta seg konsesjonsrisikoen og erklære at det er uaktuelt med salg til noen av de interessentene som konsesjonsmyndighetene måtte mene var aktuelle. Det ville gjøre en konsesjonsbehandling i tråd med lovgivers forutsetninger umulig, og slike uttalelser kan følgelig ikke tillegges noen vekt ved behandlingen. ${ }^{55}$ Selv om dommen ikke gjaldt konkurranseloven $\S 16$, kan det spørres om den har overføringsverdi til konkurranserettslig kontroll med foretakssammenslutninger. Kan melder av en foretakssammenslutning, ved tiltak eller erklæringer om hva det vil foreta seg dersom foretakssammenslutningen ikke blir klarert, umuliggjøre tilsynskontroll? Konkurranselovens forbud mot konkurransebegrensende samarbeid, misbruk av markedsdominans og implementering av foretakssammenslutninger, reduserer en eventuell risiko. Også her kan uriktige opplysninger gi grunnlag for overtredelsesgebyr, straff eller senere inngrep. Melders uttalelser kan dessuten ikke ubetinget legges til grunn, men vil være gjenstand for en konkret prediksjon. Dommen gir uansett ikke støtte for et tilbakedatert faktumtidspunkt.

\section{$4 \quad$ Konkurransetilsynets praksis: «vurderingen skal bygge på faktum (...) på tidspunktet for foretakssammenslutningen»}

Selv om «[h]ovedregelen i norsk forvaltningsrett er at vedtak skal treffes på grunnlag av de opplysninger som foreligger på vedtakstidspunktet» ${ }^{56}$, er det i Konkurransetilsynets praksis eksempler på at tilsynelatende inngrepsrelevante omstendigheter har blitt avskåret. Praksis fremstår heller ikke konsekvent og begrunnelsene varierer. Det er også hensiktsmessig å sammenligne Konkurransetilsynets praksis med enkelte foretakssammenslutningsavgjørelser fra EU-kommisjonen og danske konkurransemyndigheter.

I en sak avviste Konkurransetilsynet at en avtale som kunne avbøte foretakssammenslutningens konkurransehindrende virkninger, var relevant. I V2014-13, Nortura - Prima Slakt / NorPri / Jæren Eiendomsinvest grep Konkurransetilsynet inn mot Norturas kontrollerverv av selskapene Prima Slakt, NorPri og Jæren Eiendomsinvest. Melding innkom til Konkurransetilsynet 5. mai 2014. I vedtak 22. oktober

\footnotetext{
${ }^{54}$ Lov 28. november $2003 \mathrm{nr} .98$ om konsesjon ved erverv av fast eiendom (konsesjonsloven) mv.

${ }^{55}$ Rt. 2012 s. 18 , avsnitt 73.

56 Rt. 2013 s. 1187.
} 
s.å. fant tilsynet inngrepsgrunnlag i nasjonale markeder for hele slakt og stykket/skåret kjøtt av storfe, småfe og gris, men tillot foretakssammenslutningen på vilkår. En rammeavtale av 3. april 2014 ga selskapet Prima Kjøtt rett og plikt til å motta slakt og kjøtt fra Nortura/NorPri etter foretakssammenslutningen. Avtalen skulle sikre Prima Kjøtt tilstedeværelse i markedet ${ }^{57}$ og eliminere eventuell konkurranseskade. Konkurransetilsynet var likevel av den oppfatning at "rammeavtalen ikke kan tillegges vekt», ${ }^{58}$ og det ble blant annet vist til "rammeavtalens rene privatrettslige karakter, som avskjærer Konkurransetilsynets mulighet til å gripe inn dersom partene $i$ etterkant av foretakssammenslutningen skulle si opp avtalen eller endre denne $i$ vesentlig grad.» ${ }^{59}$ Etter tilsynets oppfatning måtte avtalen være fremsatt som et forslag til avhjelpende tiltak for å vektlegges. ${ }^{60}$ Fremfor å vurdere om avtalen sannsynlig ville etterleves og betydningen den i fall ville ha for konkurransen etter foretakssammenslutningen, frakjente tilsynet avtalen enhver betydning. ${ }^{61}$ Begrunnelsen var ikke knyttet til faktumtidspunktet for inngrepsvurderingen. Resultatet var likevel at avtalen ble utelatt fra det faktiske inngrepsgrunnlaget, selv om det var på det rene at avtalen forelå på vedtakstidspunktet. Konkurransetilsynets vedtak tok heller ikke i betraktning alminnelige forvaltningsrettslige omgjøringsregler.

Til sammenligning kan det vises til EU-kommisjonens vedtak i IV/190, Nestlé - Perrier vedrørende foretakssammenslutningsinngrep i det franske mineralvannmarkedet. Nestlé hadde inngått avtale om overdragelse av mineralvannmerket Volvic dersom kontrollervervet av Perrier ble klarert. Avtalen ville derved påvirke konkurransen med foretakssammenslutningen. EU-kommisjonen påpekte: «In its assessment of the proposed merger, the Commission must take into account any existing agreement, the implementation of which would have an appreciable impact on the future market structure. Such an agreement, like any other market element, may lead to the conclusion that the take-over of Perrier under those future market conditions cannot be declared compatible with the common market. ${ }^{62}$

Faktumtidspunktet var et mer eksplisitt tema i Konkurransetilsynets inngrepsvedtak V2017-19, Eimskip Nor Lines. Tilsynet uttalte her blant annet at «[n]ormalt vil status quo være det beste anslaget på hvordan markedet hadde utviklet seg uten foretakssammenslutningen. Med status quo menes de markedsforholdene som eksisterer $i$ det relevante markedet på tidspunktet for foretakssammenslutningen.» ${ }^{63}$ Foretakssammenslutningen var en imidlertid en fremtidig eventualitet da

\footnotetext{
${ }^{57}$ V2014-13, Nortura - Prima Slakt / NorPri / Jæren Eiendomsinvest, avsnitt 9 og 10.

${ }^{58}$ V2014-13, Nortura - Prima Slakt / NorPri / Jæren Eiendomsinvest, avsnitt 150.

${ }^{59}$ V2014-13, Nortura - Prima Slakt / NorPri / Jæren Eiendomsinvest, avsnitt 142.

${ }^{60}$ V2014-13, Nortura - Prima Slakt / NorPri / Jæren Eiendomsinvest, avsnitt 143.

${ }^{61}$ I avsnitt 144 heter det for $\varnothing$ vrig: «Rammeavtalen i nærværende sak regulerer rettigheter og plikter mellom partene i foretakssammenslutningen som tilsynet har til behandling. Dette i motsetning til saksforholdene i de avgjørelsene [fra EU-kommisjonen] partene har vist til, hvor det var tale om avtaler uten direkte tilknytning til selve transaksjonen eller forpliktelser overfor tredjepartsaktører.» Argumentet fremstår som 'a distinction without a difference' og er heller ikke faktisk korrekt da selskapet Prima Kjøtt nettopp ville være en tredjepartsaktør og ikke part i foretakssammenslutningen mellom Nortura og selskapene Prima Slakt, NorPri og Jæren Eiendomsinvest. ${ }^{62}$ Sak IV/190, Nestlé - Perrier, avsnitt 37. EU-kommisjonen fant likevel inngrepsgrunnlag uberoende av avtalen. ${ }^{63}$ V2017-19, Eimskip - Nor Lines, avsnitt 241. Se også V2015-24, Coop - ICA, avsnitt 96-97, V2017-19, Eimskip Nor Lines, avsnitt 240-241. Liknende også V2016-6, Umoe / Dolly Dimple's, avsnitt 219. Se til sammenligning Prisrådets innstilling 23. juni 1989 Procordia Abs erverv av aksjer i A/S Hansa Bryggeri, etter dagjeldende Lov 26.
} 
formuleringen ble skrevet. Formentlig mente tilsynet likevel et ikke nærmere definert fortidig tidspunkt. Deler av vedtaket er unntatt offentlighet, men også følgende uttalelse har generell interesse: "Konkurransetilsynet fastholder at tilsynet ved denne vurderingen skal bygge på faktum som forelå på tidspunktet for foretakssammenslutningen. Interne dokumenter og øvrige bevis utarbeidet etter dette tidspunktet, vil kunne være påvirket av den foreliggende transaksjon og således være lite egnet som grunnlag for tilsynets vurdering av den mest sannsynlige markedsutvikling uten foretakssammenslutningen. Dette vil også gjelde for interne beslutninger fattet etter dette tidspunkt. ${ }^{64}$ Det er uklart hvilket skjæringstidspunkt tilsynet her viser til og la til grunn. For $\emptyset v r i g$ er begrunnelsen snarere knyttet til prediksjonsverdien av vedtaksnære fakta og bevisvekt, enn argumenter for antedatering av faktumtidspunktet.

Konkurransetilsynets ovennevnte uttalelser kan sammenholdes med tilsynets behandling av foretakssammenslutningen NorgesGruppen - Tiger/Esso. I inngrepsvarsel 23. september 2015 vektla tilsynet blant annet at NorgesGruppen hadde markedstilstedeværelse for salg av kioskvarer fra bensinstasjoner gjennom en avtale med Shell om Fresh-konseptet. I henleggelsesavgjørelse A2015-2, NorgesGruppen - Tiger/Esso av 10. november 2015 fremgår det imidlertid at "[e]tter at varselet ble oversendt partene (...) har Konkurransetilsynet blitt informert om at samarbeidet mellom St1 Nordic [erverver av shell] og Norges[G]ruppen om Fresh-konseptet skal avsluttes fra nyttår. » ${ }^{65}$ Etter en nærmere vurdering kom tilsynet til at det ikke forelå inngrepsgrunnlag, blant annet fordi opphør av samarbeidet om Fresh-konseptet ville innebære at partene ikke lengre ville ha overlappende virksomhet $\mathrm{i}$ bensinstasjonssegmentet. ${ }^{66}$ Sammenholdt med vedtaket V2017-19, Eimskip - Nor Lines, problematiserte ikke tilsynet her faktumtidspunktet for inngrepsvurderingen. ${ }^{67}$

Et annet syn på faktumtidspunktet fremkommer for $\varnothing v$ rig av EU-kommisjonens klareringsvedtak COMP/M.5529, Oracle - Sun. Foretakssammenslutningen ble notifisert 30. juli 2009. EU-kommisjonen hadde innsigelser blant annet som følge av konkurranseflaten mellom Oracles databaser og Suns MySQLdatabaser, og det ble derfor innledet grundigere unders $\varnothing$ kelser. 14. desember 2009 ga Oracle en pressemelding og annonserte løfter om blant annet videreutvikling av MySQ etter foretakssammenslutningen. ${ }^{68}$ Annonseringen ble vektlagt i EU-kommisjonens klareringsvedtak 21. januar 2010. EU-kommisjonen presiserte at det ikke dreide seg om formelle avhjelpende tiltak ${ }^{69}$, men at

juni 1953 nr. 4 om kontroll og regulering av priser, utbytte og konkurranseforhold, § 42 a, der Prisrådet uttalte (side 36) at det må oppstilles «en hypotese om hvilken markedsutvikling en kan få hvis ervervet finner sted, og hvilken markedsutvikling en får hvis det gripes in mot ervervet».

${ }^{64}$ V2017-19, Eimskip - Nor Lines, avsnitt 283.

${ }^{65}$ A2015-2, NorgesGruppen - Tiger/Esso underretning om henleggelse, avsnitt 16.

${ }^{66}$ A2015-2, NorgesGruppen - Tiger/Esso underretning om henleggelse, avsnitt 19.

67 Se også V2018-19, St1 Norge - Statoil Fuel \& Retail Marine, der Konkurransetilsynet blant annet kom til at det likevel ikke var inngrepsgrunnlag i Kirkenes-området da Cirkle K i etterkant av inngrepsvarselet meddelte salg av et tankanlegg i Kirkenes. Konkurransetilsynet påpekte her at salgsprosessen hadde funnet sted uavhengig av foretakssammenslutningen, jf. avsnitt 526. Konkurransetilsynet synes dessuten å erkjenne at faktiske endringer i saksbehandlingsperioden kan gi grunnlag for dispensasjon fra gjennomføringsforbudet, jf. konkurranseloven $\S 19$ annet ledd og f.eks. A2013-9, Jotunfjell Partners - Fyllingsdalen Foto.

68 www.oracle.com/us/corporate/press/042364

${ }^{69}$ COMP/M.5529, Oracle - Sun, avsnitt 177. 
annonseringen inngikk i inngrespvurderingens faktiske grunnlag: "[T]he Commission considers that the public announcement made by Oracle on 14 December, addressed to the general public and in particular to the open source community, and the subsequent actions already taken to implement part of this announcement, constitute factual elements that the Commission must take into account in this case, along with all the other elements in its file in its assessment of the impact of the proposed transaction on the database market». ${ }^{70}$ At vedtaksnære og foretakssammenslutningsbetingede faktiske hendelser ikke avskjæres av et antedatert faktumtidspunkt, er klart nok ikke til hinder for at hendelsestidspunktet og $\emptyset$ vrige omstendigheter kan påvirke prediksjonsverdien. ${ }^{71}$

Konkurransetilsynet har ved én anledning også avvist relevansen av en inngått avtale som skulle effektueres dersom foretakssammenslutningen ikke ble gjennomført. I V2015-1, TeliaSonera - Tele2 / Network Norway av 5. februar 2015 kom tilsynet til at konkurransesituasjonen, som ble betegnet som status quo, ikke kunne legges til grunn for virkningsvurderingen. Årsaken var at Tele2 ikke hadde vunnet radiofrekvenser i Nasjonal kommunikasjonsmyndighets (Nkoms) frekvensauksjon i desember 2013. Tapet av frekvenser innebar at Tele2 ikke alene kunne fortsette som mobilnettverksoperat $\varnothing$ r (MNO). ${ }^{72}$ Spørsmålet var hvilken konkurransesituasjon som da var sannsynlig uten foretakssammenslutningen. Dersom Tele2 på annen måte ville fortsette som MNO, ville foretakssammenslutningen innebære en 3 til 2 reduksjon ${ }^{73}$ i grossistmarkedet. ${ }^{74}$ Dersom det derimot var sannsynlig at Tele2 ville fortsette som mobil virtuell nettverksoperat $\varnothing r$ (MVNO), ville foretakssammenslutningen ikke være årsak til en konkurransereduksjon i grossistmarkedet. I henhold til MVNO-avtale 4. juli 2014 ville Tele2 operere som MVNO med tilgang til TeliaSoneras nett og frekvenser dersom foretakssammenslutningen ikke ble gjennomført. Overfor tilsynet ble det følgelig argumentert med at MVNO-avtalen måtte legges til grunn for vurderingen av konkurransesituasjonen uten foretakssammenslutningen. ${ }^{75}$

Konkurransetilsynet uttalte også her at «[n]ormalt vil status quo være det beste anslaget på hvordan markedet hadde utviklet seg uten foretakssammenslutningen. Med status quo menes de markedsforholdene som eksisterer $i$ det relevante markedet på tidspunktet for foretakssammenslutningen.» ${ }^{76}$ Under tilsynets forhåndskontroll vil foretakssammenslutningen ligge i fremtiden, ikke være gjennomført og nettopp være betinget av tilsynets klarering. Implikasjonen var likevel tilsynelatende at faktumtidspunktet for inngrepsvurderingen ble antedatert fra vedtakstidspunktet, og at MVNO-avtalen ikke ble tilkjent relevans. I vedtaket heter det blant annet at «MVNO-avtalen mellom Tele2 og TeliaSonera av 4. juli 2014 [ville ikke] blitt inngått uten foretakssammenslutningen (...).» ${ }^{77}$ Betegnende er også tilsynets formulering om at MVNO-scenarioet "var [ikke «er»] et lite sannsynlig

${ }^{70}$ COMP/M.5529, Oracle - Sun, avsnitt 181.

${ }^{71}$ Se til eksempel COMP/M.5599, Amcor - Alcan, avsnitt 118 og note 41.

72 V2015-1, TeliaSonera - Tele2 / Network Norway, avsnitt 228-238.

73 Telenor + TeliaSonera/Tele2/Network Norway.

${ }^{74}$ Markedet for tilgang til og samtaleoriginering i mobilnett.

${ }^{75}$ V2015-1, TeliaSonera - Tele2 / Network Norway, avsnitt 236.

${ }^{76}$ V2015-1, TeliaSonera - Tele2 / Network Norway, avsnitt 181-182. Med videre henvisninger. Se til sammenlikning Konkurransetilsynets vedtak V2019-17, Sector Alarm - Nokas, der bruker tre ulike formuleringer: «tidspunktet for ervervet» (avsnitt 164), «konkurransesituasjonen før foretakssammenslutningen» (avsnitt 165-166) og «tidspunktet for foretakssammenslutningen og minoritetservervet» (avsnitt 169).

77 V2015-1, TeliaSonera - Tele2 / Network Norway, avsnitt 237. Se liknende avsnitt 248, 250 og 251-256. 
alternativ uten foretakssammenslutningen. $)^{78}$ Det innebar at MVNO-avtalen, som vitterlig var inngått på vedtakstidspunktet, likevel ikke skulle inngå $i$ inngrepsvurderingen. Tilsvarende fremstår tilsynets vurdering av MNO-scenarioet også knyttet til et tidspunkt før MVNO-avtalen ble inngått. Tilsynet viste blant annet til at Tele2 «parallelt med salgsprosessen med TeliaSonera forhandlet med ICE om mulige løsninger». ${ }^{79}$ Med et faktumtidspunkt som tilsynelatende lå før juli 2014, i et vedtak fra februar 2015, fant tilsynet at «MNO-scenarioet er den mest sannsynlige markedsutviklingen uten foretakssammenslutningen (alternativsituasjonen).» ${ }^{80}$ Det fremstår likevel ikke klart hvorfor faktumtidspunktet skulle antedateres, tilsynelatende til fortrengsel for sakens faktiske omstendigheter på vedtakstidspunktet og det forvaltningsrettslige utgangspunktet.

Avgjørelsen i V2015-1, TeliaSonera - Tele2 / Network Norway har imidlertid en parallell i det danske Konkurrencerådets behandling av faktumtidspunktet under SIEC-standarden. I avgjørelse av 28. mai 2014 godkjente rådet, på vilkår, foretakssammenslutningen mellom EY og KPMG Danmark. I tråd med transaksjonsavtalen 18. november 2013 hadde KPMG Danmark samme dag terminert samarbeidet med KPMG International. Konkurrencerådet var likevel av den oppfatning at inngrepsvurderingen skulle se bort fra KPMG Danmarks uttreden fra det internasjonale KPMG-nettverket og baseres på situasjonen før transaksjonsavtalen. ${ }^{81}$ Konkurrencerådet uttalte generelt at "[i] det omfang, der er foretaget fusionsspesifikke dispositioner, skal udenfusionsscenariet fastlægges uden inddragelse af disse. Fusionsspecifikke dispositioner skal alene inddrages i fusionsscenariet.. ${ }^{82}$ En slik norm er ikke i samsvar med Konkurransetilsynets behandling av ovennevnte rammeavtale i V2014-13, Nortura - Prima Slakt / NorPri / Jæren Eiendomsinvest, men kan synes å svare til tilsynets behandling av MVNO-avtalen i V20151, TeliaSonera - Tele2 / Network Norway. Likevel forklarte heller ikke Konkurrencerådet hvorfor konkurransesituasjonen uten foretakssammenslutningen skulle baseres på faktum på fusjonsavtaletidspunktet og ikke inngrepsvedtakstidspunktet. Som anført av partene, kunne de faktiske markedsforholdene på avtaletidspunktet uansett ikke gjenetableres.

En mulig forklaring kan være at både danske og norske konkurransemyndigheter uriktig har ansett forbudet mot gjennomføring av meldepliktige foretakssammenslutninger, som et vidtgående atferdsforbud og ikke som et foretaksstrukturendringsforbud. ${ }^{83}$ Dersom fusjonsspesifikke markedshandlinger ville ha vært i strid gjennomføringsforbudet, kunne det kanskje tilsi å utelukke slike fra inngrepsvurderingen. Konkurrencerådet fattet $\mathrm{i}$ så måte et etterfølgende vedtak om at KPMG Danmarks oppsigelse av samarbeidet med KPMG International, var i strid med gjennomføringsforbudet. ${ }^{84}$ I foreleggelsesavgjørelsen i EY mot Konkurrencerådet 31. mai 2018 kom derimot EU-domstolen blant annet til at oppsigelsen av en slik samarbeidsavtale ikke kunne anses som en gjennomføring av en

\footnotetext{
78 V2015-1, TeliaSonera - Tele2 / Network Norway, avsnitt 248.

${ }^{79}$ V2015-1, TeliaSonera - Tele2 / Network Norway, avsnitt 260.

${ }^{80}$ V2015-1, TeliaSonera - Tele2 / Network Norway, avsnitt 282.

${ }^{81}$ Konkurrencerådets avgjørelse 28. mai 2014, EY's overtagelse af KPMG Danmark, avsnitt 380-381.

${ }^{82}$ Konkurrencerådets avgjørelse 28. mai 2014, EY's overtagelse af KPMG Danmark, avsnitt 374.

${ }^{83}$ Se f.eks. V2014-14, Easy - Britannia Hotel.

${ }^{84}$ Konkurrencerådets avgjørelse 17. desember 2014, Overtrædelse af præimplementeringsforbuddet i forbindelse med EY's overtagelse af KPMG Danmark.
} 
foretakssammenslutning. ${ }^{85}$ 7. september 2018 meddelte Konkurrencerådet at de aksepterte EYs påstand om opphevelse av vedtaket om overtredelse av gjennomføringsforbudet i den da verserende saken for Sø- og Handelsretten. ${ }^{86}$

\section{$5 \quad$ Faktumtidspunktet for Konkurranseklagenemndas klagevedtak}

Konkurranseklagenemnda ble opprettet ved lov 15. april 2016 nr. 2 om endringer i konkurranseloven (Konkurranseklagenemnda, kartellforlik mm.) og trådte i kraft 1. april 2017. ${ }^{87}$ Nemnda skal behandle klager over tilsynets vedtak og avgjørelser, ${ }^{88}$ og nemndas kompetanse tilsvarer departementets tidligere klagesakskompetanse.

Endrede faktiske forhold i klagebehandlingsperioden kan også innvirke på en vurdering av foretakssammenslutningens konkurransevirkninger. Klagefristen på Konkurransetilsynets inngrepsvedtak er 15 virkedager. Tilsynet skal bringe klagen inn for nemnda innen ytterligere 15 virkedager, hvorpå nemnda må treffe vedtak innen 60 virkedager. ${ }^{89}$

Faktumtidspunktet for Konkurranseklagenemndas klagevedtak er ikke direkte regulert i konkurranseloven, men følger av alminnelige forvaltningsrettslige regler. Nemnda er et uavhengig forvaltningsorgan ${ }^{90}$ underlagt forvaltningens generelle utredningsplikt. ${ }^{91}$ Klagereglene i forvaltningsloven kapittel VI gjelder dessuten så langt de passer. ${ }^{92}$ Forvaltningsloven $\S 34$ annet ledd angir at klageinstansen kan «prøve alle sider av saken og herunder ta hensyn til nye omstendigheter. ${ }^{93}$ Det siste innebærer at klageinstansen normalt skal hensynta faktiske endringer etter et påklagd vedtak. ${ }^{94}$ Departementets tidligere praksis i klager om foretakssammenslutningsinngrep, synes for $\varnothing$ vrig å anerkjenne at de faktiske forholdene på klagevedtakstidspunktet er avgjørende for inngrepsvurderingen i klagesaken. ${ }^{95}$

\footnotetext{
${ }^{85}$ Sak C-633/16, Ernst \& Young mot Konkurrencerådet, ECLI:EU:C:2018:23.

${ }^{86}$ Konkurrencerådets pressemelding: www.kfst.dk/pressemeddelelser/kfst/2018/20180907-ey-paastand-omimplementering-af-fusion-accepteres/

87 Konkurranseloven fikk med det et nytt kapittel 8 Klagenemnd for konkurransesaker.

88 Jf. konkurranseloven $\S 35$. Tredjeparter har ikke klagerett over beslutninger om ikke å gripe inn eller mot tillatelser på vilkår, se Ot.prp. nr. 6 (2003-2004) om lov om konkurranse mellom foretak og kontroll med foretakssammenslutninger (konkurranseloven), side 230 og 233, Prop. 75 L (2012-2013) Endringer i konkurranseloven, side 99 og NOU 2014:11 Konkurranseklagenemnda - Etablering av et uavhengig klageorgan for konkurransesaker, side 29.

89 Jf. konkurranseloven $\S 20$ a.

90 Jf. konkurranseloven § 8. Se nærmere Prop. 37 L (2015-2016) Endringer i konkurranseloven (Konkurranseklagenemnda, kartellforlik mm.), side 42.

91 Jf. forvaltningsloven $\S 17$ første ledd.

92 Jf. konkurranseloven $\S 20$ a. Lovhenvisningen til forvaltningslovens klageregler var opprinnelig inntatt i konkurranseloven (2004) § 20 fjerde ledd fjerde punktum.

${ }^{93}$ Se for $\varnothing$ vrig Prop. 37 L (2015-2016) Endringer i konkurranseloven (Konkurranseklagenemnda, kartellforlik mm.), side 30 og 42.

${ }^{94}$ Se Jan Fridthjof Bernt, Gyldendal Rettsdata, note 883 til forvaltningsloven og Torstein Eckhoff og Eivind Smith, Forvaltningsrett, 10. utgave, Universitetsforlaget 2014, side 300.

${ }^{95}$ Se departementets vedtak 13. juli 2017 - klage på Konkurransetilsynets vedtak V2014-4 - St1 Nordic Oy - Blue Energy Holding AS - Blue Energy Holding AS godkjennes som kjøper av St1 Norge Automat AS, side 15. Se også departementets vedtak 20. januar 2017 - klage på Konkurransetilsynets vedtak V2016-6 foretakssammenslutning mellom Umoe Restaurants AS og Dolly Dimple's Norge AS, punkt 7.
} 
Konkurranseklagenemndas kompetanse er likevel begrenset for klager over vedtak om foretakssammenslutningstillatelser på vilkår. ${ }^{96}$ I slike saker kan nemnda bare oppheve eller stadfeste tilsynets vedtak, jf. konkurranseloven $\S 20$ a første ledd femte punktum. Dette innebærer at nemnda ikke kan tillate en foretakssammenslutning på andre avhjelpende tiltak enn de som følger av tilsynsvedtaket. Kompetansebegrensningen er den samme som for departementet etter tidligere klageordning, og den ble tilføyd ved lov 14 juni 2013 nr. 35 om endringer i konkurranseloven. ${ }^{97}$ Konkurransetilsynet fikk samtidig kompetanse til å avslutte saker om konkurranseskadelig atferd med vedtak om bindende avhjelpende tiltak. ${ }^{98}$

Konkurranselovens begrensning av klageorganets kompetanse vil nok også måtte gjelde der Konkurransetilsynet presiserer avhjelpende tiltak i avledede vedtak. Dette kan eksempelvis være situasjonen der et opprinnelig inngrepsvedtak tillater en foretakssammenslutning på vilkår om at en delvirksomhet avhendes til en egnet og uavhengig kjøper. Et senere avledet tilsynsvedtak som avviser eller godkjenner en aktuell kjøper, kan konkretisere kravene til egnethet og uavhengighet. Når klageorganets kompetanse er begrenset ved klage over vedtak etter konkurranseloven § 16 annet ledd, er det vanskelig å se noen grunn til at ikke kompetansen skulle være tilsvarende begrenset ved klage over vedtak etter vedtak etter konkurranseloven $\S 16$ annet ledd. Departementets begrunnelser for kompetansebegrensningen er like treffende i begge tilfeller. ${ }^{99}$ Klageorganet har derfor neppe kompetanse til eksempelvis å godkjenne en kjøper tilsynet har avvist - på nye avbøtende tiltak. I juli 2017 fattet imidlertid departementet et vedtak der Blue Energy Holding AS ble godkjent som kjøper av St1 Norge på ytterligere avhjelpende vilkår. ${ }^{100}$ Departementet opphevet samtidig Konkurransetilsynets vedtak V20164, der Blue Energy Holding AS ikke ble godkjent som kjøper etter vilkårene i det opprinnelige inngrepsvedtaket V2015-29, St1 Nordic - Smart Fuel (Shell). Departementets godkjenningsvedtak reiser for $\varnothing v$ rig en rekke spørsmål knyttet til blant annet (u)gyldighet, meldeplikt, ${ }^{101}$ gjennomf $\varnothing$ ringsforbud, ${ }^{102}$ og forbudet mot konkurransebegrensende samarbeid. ${ }^{103}$

Ved klage over forbudsvedtak ${ }^{104}$ følger ikke begrensningen om at nemndas vedtak bare kan gå ut på å oppheve eller stadfeste tilsynsvedtaket uttrykkelig av loven. Når nemndas kompetanse er begrenset ved klager over inngrep på avbøtende vilkår, er det vanskelig å se at nemnda skulle ha kompetanse til å tillate

\footnotetext{
96 Jf. konkurranseloven $\S 16$ annet ledd.

97 I kraft 1. januar 2014. Prop. 75 L (2012-2013) Endringer i konkurranseloven, side 149: «Departementets kompetanse er i slike saker begrenset til å prøve om vedtaket er gyldig, det vil si om de materielle inngrepsvilkårene er oppfylt og om det avhjelpende tiltaket er egnet og forholdsmessig, og om det foreligger saksbehandlingsfeil som fører til opphevelse.» Ved samme endringslov ble tilsynets adgang til inngrep på avhjelpende vilkår endret fra vilkårslæren til at tiltakene må være foreslått av melder, jf. konkurranseloven § 16 annet ledd.

98 Jf. konkurranseloven $\S 12$ tredje ledd.

99 Se Prop. 75 L (2012-2013) Endringer i konkurranseloven, side 149 og 99, jf. side 31, Prop. 37 L (2015-2016)

Endringer i konkurranseloven (Konkurranseklagenemnda, kartellforlik mm.), side 81, jf. side 79 og 43.

100 Departementets vedtak 13. juli 2017 - klage på Konkurransetilsynets vedtak V2014-4 - St1 Nordic Oy - Blue

Energy Holding AS - Blue Energy Holding AS godkjennes som kjøper av St1 Norge Automat AS.

101 Jf. konkurranseloven $\S \S 17$ og 18.

102 Jf. konkurranseloven $\S 19$.

103 Jf. konkurranseloven § 10 og EØS artikkel 53.

104 Jf. konkurranseloven § 16 første ledd.
} 
foretakssammenslutning på avbøtende vilkår ved klager over forbudsvedtak. Kompetansebegrensningen vil nok derfor måtte gjelde også i sistnevnte tilfeller, men det hadde her vært ønskelig med en klarere lovregulering.

Det kan stilles spørsmål ved sammenhengen mellom en klageordning der vedtak treffes på grunnlag av faktum på klagevedtakstidspunktet, og begrensningen av klageorganets kompetanse til å tillate foretakssammenslutninger på (endrede) avhjelpende tiltak. Temaet er berørt i Prop. 75 L (2012-2013) Endringer i konkurranseloven i tilknytning til departementets vurdering av forslag om lovhjemmel for vedtak om avhjelpende tiltak i saker om konkurranseskadelig atferd. Av lovproposisjonen fremgår det at "[d]epartementet ser ikke grunnlag for en regel, slik Regjeringsadvokaten foreslår, om at klagesaksbehandlingen må skje på grunnlag av det faktum som forelå for Konkurransetilsynet når vedtak ble fattet. Dersom klager anfører at atferden ikke har konkurransebegrensende virkninger, må dette vurderes på grunnlag av det faktum som er tilgjengelig for departementet i klagebehandlingen, slik som ved annen klagesaksbehandling etter loven.» ${ }^{105}$ Departementet gikk dermed tilsynelatende åpent inn for at faktumtidspunktet tilsvarer klagevedtakstidspunktet. ${ }^{106}$ Klageorganet skulle likevel ikke ha kompetanse til å tillate foretakssammenslutningen på (andre) avbøtende vilkår, selv om endrede faktiske forhold skulle åpne for det.

Konkurranseklagenemndas begrensede kompetanse i saker om avhjelpende tiltak, hadde nok likevel vært bedre tilpasset en prøvingsordning med grunnlag i faktum på tidspunktet for Konkurransetilsynets vedtak. Dersom melder iverksetter uformelle, faktiske avhjelpende tiltak under klagesaksbehandlingen som fjerner inngrepsgrunnlaget, skal Konkurranseklagenemnda ta hensyn til de nye omstendighetene og eventuelt oppheve inngrepsvedtaket. ${ }^{107}$ Gjennomføringsforbudet i konkurranseloven $\S 19$ er da heller ikke til hinder for at foretakene implementerer markedsatferd under foretakssammenslutningsbehandlingen. ${ }^{108}$ Konkurranseklagenemnda har likevel ikke adgang til å tillate foretakssammenslutningen dersom tilsvarende tiltak foreslås som nye formelle avhjelpende tiltak. Klageordningsreglene gir dermed insentiver til uformelle, faktiske avhjelpende tiltak, selv om formelle vedtak om foretakssammenslutningstillatelser på tilsvarende vilkår, kunne ha gitt ytterligere håndhevingmuligheter og etterlevelsessikkerhet. ${ }^{109}$ En mer konsistent løsning ville ha vært at klageorganet hadde kompetanse til å tillate foretakssammenslutninger på (endrede) vilkår, eller at klagebehandlingen bygde på faktumtidspunktet for tilsynets inngrepsvedtak. Til sammenligning nevnes kontrollen med EU-kommisjonens vedtak om inngrep eller klarering av foretakssammenslutninger, der det er på det rene at "the legality of the contested decision must be assessed on the basis of the facts existing at the time when the measure was adopted and not in the light of subsequent events». ${ }^{110}$

\footnotetext{
105 Prop. 75 L (2012-2013) Endringer i konkurranseloven, side 99 jf. side 31. I departementets vurderinger i foretakssammenslutningssaker vises det til omtalen av klagebehandlingen i atferdssaker.

${ }^{106}$ Se for øvrig departementets vedtak 20. januar 2017 - klage på Konkurransetilsynets vedtak V2016-6 foretakssammenslutning mellom Umoe Restaurants AS og Dolly Dimple's Norge AS, punkt 7. Departementet synes implisitt å anerkjenne at endrede omstendigheter inngår i klageorganets faktagrunnlag.

107 Saken er da endelig avgjort, jf. også konkurranseloven $\S 20$ a annet ledd første punktum.

108 Jf. konkurranseloven § 19 og sak C-633/16, Ernst \& Young mot Konkurrencerådet, ECLI:EU:C:2018:23.

109 Jf. konkurranseloven $\S 29$.

${ }^{110}$ Sak T-282/06, Sun mot Kommisjonen, ECLI:EU:T:2007:203, avsnitt 59. (Med videre henvisninger)
} 


\section{Faktumtidspunktet for domstolskontroll med inngrepsvedtak}

Faktiske hendelser som inntrer etter at det er iverksatt domstolsbehandling av inngrepsvedtak, kan også innvirke på foretakssammenslutningens konkurransevirkninger. Søksmålsfristen er tre måneder etter at underretning om Konkurranseklagenemndas vedtak er mottatt. ${ }^{111}$ S $\varnothing \mathrm{ksmål}$ skal rettes mot staten ved Konkurransetilsynet og anlegges for Gulating lagmannsrett. ${ }^{112}$ Verken tilsynet eller departementet kan anlegge søksmål om nemndas vedtak. ${ }^{113}$

I utgangspunktet fører domstolene kontroll med om et forvaltningsvedtak lå innenfor rettsreglene da det ble fattet, ikke om det deretter og fram til domstidspunktet har inntrådt nye omstendigheter som kunne tilsagt et annet resultat. ${ }^{114}$ I plenumsdommen i Rt. 2012 s. 1985, om utlendingsmyndighetenes avslag på søknad om asyl og opphold, kom flertallet til at faktum på vedtakstidspunktet, ikke domstidspunktet, skulle legges til grunn for domstolsprøvingen. ${ }^{115}$ । flertallsvotumet ble det blant annet uttalet at "høyesterettspraksis gir et klart bilde av at domstolskontrollen knytter seg til faktum på vedtakstidspunktet, med mindre det motsatte følger av en naturlig tolkning av loven.» ${ }^{116}$ Det vil likevel være adgang til å fremlegge nye bevis som kaster lys over situasjonen på vedtakstidspunktet. ${ }^{117}$

111 Jf. konkurranseloven $\S 39$ tredje ledd første punktum.

112 Jf. konkurranseloven $\S 39$ fjerde ledd. For nærmere begrunnelse, se Prop. 37 L (2015-2016) Endringer i konkurranseloven (Konkurranseklagenemnda, kartellforlik mm.), side 89.

${ }^{113}$ Se nærmere NOU 2014:11 Konkurranseklagenemnda - Etablering av et uavhengig klageorgan for konkurransesaker, side 132-133.

114 Torstein Eckhoff og Eivind Smith, Forvaltningsrett, 10. utgave, Universitetsforlaget 2014, s. 520-521.

115 Rt. 2012 s. 1985, avsnitt 98. Problemstillingen ble i flertallsvotumet (avsnitt 50) presisert på følgende måte: «[T]radisjonelt skilles [det] mellom nye rettsfakta og nye bevisfakta. Nye rettsfakta er nye faktiske forhold som direkte og umiddelbart har rettslige følger, mens nye bevisfakta er nye bevis som godtgjør rettsfrakta (...). Nye bevisfakta som kaster lys over forholdene på vedtakstidspunktet, er det i utgangspunktet adgang til å påberope seg (...). Spørsmålet er om det også er adgang til å påberope nytt rettsfaktum for domstolene, altså nytt rettsstiftende faktum som har oppstått etter forvaltningsvedtaket, og som deretter ikke har vært vurdert av forvaltningen.» Se for øvrig Rt. 2012 s. 2039, Rt. 2013 s. 449, Rt. 2015 s. 93 og Rt. 2015 s. 1388.

116 Rt. 2012 s. 1985, avsnitt 79. Se også Rt. 2012 s. 2039, avsnitt 38. Om omgjøringsvedtak, se Rt. 2013 s. 1424 , avsnitt 37. Se nærmere Gunnar O. Hæreids tre artikler, 'Tidspunkt for faktumvurderinga ved domstolsprøving av forvaltningsvedtak - rettstilstanden før mai 2012', Lov og rett, 2012 nr. 8, s. 451-472, 'Tidspunkt for faktumvurderinga - rettstilstanden etter mai 2012', Lov og rett, 2012 nr. 9, s. 533-551 og 'Tidspunkt for faktumvurderinga - rettstilstanden etter desember 2012' , Lov og rett, 2013 nr. 5, s. 337-344.

117 Jf. Rt. 2015 s. 1388, avsnitt 132 og Rt. 2012 s. 1985, avsnitt 81. I Rt. 1982 s. 241, om gyldigheten av kgl. res. av 15. juni 1979 om utbygging av Altavassdraget, forklarte Høyesterett (side 266) at «[i] og med at det her dreier seg om prognoser som etter sin art vil være forbundet med usikkerhet, må saksbehandlingen være i orden dersom prognosene er forsvarlige på den tid de må foretas. Er prognosene forsvarlige, vil det også vanskelig bli tale om å anse utbyggingsvedtaket ugyldig på grunn av uriktige faktiske forutsetninger selv om utviklingen skulle ta en annen retning eller nyere kunnskap skulle gjøre det mulig å oppstille bedre prognoser.» Se også Rt. 2012 s. 1985, avsnitt 77. Her kan det oppstå tvilsspørsmål om hvor langt domstolene kan åpne for bevisføring som viser at utviklingen har tatt en annen retning enn prognosen for å underbygge at prognosen ikke var forsvarlig. Se nærmere Gunnar O. Hæreid, 'Tidspunkt for faktumvurderinga ved domstolspr $\varnothing v i n g$ av forvaltningsvedtak - rettstilstanden $f \varnothing r$ mai 2012', Lov og rett, 2012 nr. 8, s. 451-472, på side 460-463 og Gunnar O. Hæreid, 'Tidspunkt for faktumvurderinga rettstilstanden etter desember 2012', Lov og rett, 2013 nr. 5, s. 337-344, på side 340. 
Dette utgangspunktet gjelder ikke der retten kan "prøve alle sider av saken». Formuleringen tilsier at prøvingen da skjer ut fra de faktiske forholdene når saken tas opp til doms. ${ }^{118}$ । Rt. 2012 s. 1985 forklarte førstvoterende i så måte at «[f]or visse forvaltningsvedtak er det lovbestemt at domstolene skal vurdere situasjonen på domstidspunktet. Dette gjelder blant annet saker om administrative tvangsvedtak i helseog sosialsektoren som omfattes av tvisteloven kapittel 36. Etter lovens § 36-5 tredje ledd skal retten prøve alle sider av saken. Det er ikke tvilsomt at dette innebærer at domstolene må prøve saken slik den står på domstidspunktet.»119

Når det gjelder domstolskompetansen i saker om Konkurranseklagemendas vedtak, følger det av konkurranseloven at «[r]etten kan prøve alle sider av saken.», jf. § 39 tredje ledd tredje punktum.

Før endringene av konkurranseloven i kraft 1. april 2017, var bestemmelsen om at "[r]etten kan prøve alle sider av saken» forbeholdt domstolsprøvingen av vedtak om overtredelsesgebyr - som da heller ikke kunne påklages. ${ }^{120}$ I NOU 2014:11 Konkurranseklagenemnda - Etablering av et uavhengig klageorgan for konkurransesaker ble det uttrykt at hensynene for omfattende domstolsprøving av gebyrsaker, ikke gjør seg gjeldende i fusjonssaker eller andre konkurransesaker. Utvalget var derfor av den oppfatning at "[o]verprøving av andre saker enn gebyrsakene bør (...) behandles etter de ordinære reglene om domstolskontroll med forvaltningsvedtak. ${ }^{121}$ Domstolenes prøvingskompetanse ble tilsynelatende ikke drøftet i Prop. 37 L (2015-2016) Endringer i konkurranseloven (Konkurranseklagenemnda, kartellforlik $\mathrm{mm}$.). ${ }^{122}$ Det er dermed uklart hva som var formålet med å utvide bestemmelsens virkeområde, og hva denne endringen var ment å innebære er heller ikke kommentert i lovproposisjonen.

Konkurranseloven $\S 39$ tredje ledd tredje punktum om at «[r]etten kan prøve alle sider av saken», gjelder generelt, herunder for prøvingen av nemdas vedtak i saker om inngrep mot foretakssammenslutninger. Uttrykket "alle sider av saken" tyder på at domstolen skal prøve faktum ut fra en nåtidsvurdering. Dette innebærer i så fall at Gulating lagmannsrett ved prøvingen av Konkurranseklagenemndas vedtak i inngrepssaker skal bygge på faktum og markedsforhold på domstidspunktet. Et

\footnotetext{
118 Se også Torstein Eckhoff og Eivind Smith, Forvaltningsrett, 10. utgave, Universitetsforlaget 2014, s. 520-521.

119 Rt. 2012 s. 1985, avsnitt 53. Se nærmere Gunnar O. Hæreid, 'Tidspunkt for faktumvurderinga ved domstolspr $\varnothing$ ving av forvaltningsvedtak - rettstilstanden før mai 2012', Lov og rett, 2012 nr. 8, s. 451-472, på side 463: «Det er ikkje tvil om at det inneber at domstolane prøver faktum ut frå ei notidsvurdering, og vidare at det er høve til å gå utanfor påstandsgrunnlaga partane har gjort gjeldande, og bevis som ikkje er dokumenterte i retten.» 120 Jf. tidligere $§ 29$ tredje ledd.

${ }^{121}$ NOU 2014:11 Konkurranseklagenemnda - Etablering av et uavhengig klageorgan for konkurransesaker, side 132.

122 I merknadene til § 39 tredje ledd viser lovproposisjonen til merknadene i tidligere forarbeider, jf. Prop. $37 \mathrm{~L}$ (2015-2016) Endringer i konkurranseloven (Konkurranseklagenemnda, kartellforlik mm.), side 89. I Ot.prp. nr. 6 (2003-2004), side 241 (merknadene til tidligere $\S 29$ tredje ledd) ble det forklart: «Når en sak bringes inn for domstolene, har retten kompetanse til å prøve alle sider av saken og treffe realitetsavgjørelse. Rettens kompetanse tilsvarer departementets kompetanse som klageorgan i tradisjonelle forvaltningssaker.» Klageorganets kompetanse i tradisjonelle forvaltningssaker reguleres blant annet av forvaltningsloven $\S 34$ annet ledd som angir at klageinstansen kan «prøve alle sider av saken og herunder ta hensyn til nye omstendigheter.»
} 
foretakssammenslutningsinngrep skal dermed oppheves dersom senere inntrådte forhold innebærer at det ikke lenger foreligger inngrepsgrunnlag når saken tas opp til doms.

Domstolskompetansen vedrørende foretakssammenslutningstillatelser på avhjelpende vilkår er ikke uttrykkelig regulert i konkurranseloven. Lovens ordning er at Konkurransetilsynet kan fatte inngrepsvedtak der en foretakssammenslutning tillates på avbøtende vilkår etter forslag fra melder, jf. konkurranseloven $\S 16$ annet ledd. Konkurranseklagenemnda kan, som nevnt, ikke kan tillate en foretakssammenslutning på andre avhjelpende tiltak enn de som følger av Konkurransetilsynets vedtak, jf. konkurranseloven $\S 20$ a. Dette tilsier at en tilsvarende kompetansebegrensning gjelder ved domstolsprøving av nemndas vedtak.

Også her kan det stilles spørsmål ved sammenhengen mellom domstolskontroll med foretakssammenslutningsinngrep basert på faktum på domstidspunktet og en begrensning av rettens kompetanse til å tillate foretakssammenslutninger på (endrede) avhjelpende tiltak. En slik prøvingsordning tilskynder foretakene til heller å gjennomføre uformelle tiltak som fjerner inngrepsgrunnlaget, med den følge at retten skal oppheve foretakssammenslutningsinngrepet. Til sammenligning ville en begrensning av rettens kompetanse vedrørende avhjelpende tiltak, ha vært bedre avpasset en alminnelig legalitetskontroll knyttet til faktum på vedtakstidspunktet, tilsvarende EUkonkurranserettens ordning.

\section{$7 \quad$ Avslutning}

Konkurranseloven $\S 16$ pålegger Konkurransetilsynet å gripe inn mot kvalifisert konkurranseskadelige foretakssammenslutninger, enten med forbud eller med tillatelser på avbøtende vilkår forslått av melder. Inngrepsvurderingen krever en prediksjon av en potensiell, fremtidig foretakssammenslutnings konkurransevirkninger. Utfallet av prediksjonen beror på det godtgjorte faktumet på tidspunktet til grunn for inngrepsvurderingen.

Det alminnelige forvaltningsrettslige utgangspunktet tilsier at Konkurransetilsynets inngrepsvurdering skal skje på grunnlag av de faktiske omstendighetene på vedtakstidspunktet. Konkurransetilsynet har undertiden likevel fremholdt «tidspunktet for foretakssammenslutningen» som et skjæringstidspunkt, selv om foretakssammenslutningen da ennå ikke er gjennomført. Med formuleringen synes tilsynet likevel å vise til et rettslig faktumtidspunkt $f \varnothing r$ vedtakstidspunktet, slik at etterfølgende faktiske forhold ikke skal tillegges betydning. Et slikt tidligere faktumtidspunkt kan $\emptyset$ ke risikoen for at enkelte konkurransefremmende foretakssammenslutninger vil bli gjenstand for inngrep og at enkelte konkurranseskadelige foretakssammenslutninger tillates.

Konkurranseklagenemndas klagebehandling skal "prøve alle sider av saken og herunder ta hensyn til nye omstendigheter». Ved klager over foretakssammenslutningstillatelser på vilkår, kan nemnda likevel bare oppheve eller stadfeste tilsynets vedtak. Konsekvensen av dette er at nemnda vil måtte klarere foretakssammenslutninger der melder under klagebehandlingen gjennomfører uformelle, faktiske avhjelpende tiltak som fjerner inngrepsgrunnlaget. Nemnda har likevel ikke kompetanse til å fatte vedtak om å tillate foretakssammenslutningen på tilsvarende avhjelpende vilkår. 
Domstolskompetansen etter lovendring i 2017 er at "[r]etten kan prøve alle sider av saken» tilsynelatende også i foretakssammenslutningssaker. Formuleringen tyder på at prøvingen skal skje ut fra de faktiske forholdene på domstidspunktet. Selv om retten ikke har kompetanse til å tillate foretakssammenslutninger på avbøtende vilkår, kan foretakene da likevel gjennomføre faktiske avhjelpende tiltak som fjerner inngrepsgrunnlaget. En mer konsistent løsning kunne ha vært at Konkurranseklagenemnda og domstolen hadde kompetanse til å tillate foretakssammenslutninger på (nye) avhjelpende vilkår, eller at prøvingen skulle skje ut fra de faktiske omstendighetene på tidspunktet for tilsynets inngrepsvedtak. 